\title{
PHYSICOCHEMICAL AND ORGANOLEPTIC PROPERTIES OF DRIED SYNBIOTICS YOGHURT FROM LESSER YAM TUBERS (Dioscoreaesculenta L.)
}

\author{
Sri Winarti ${ }^{1 *}$ and Erwan Adi Saputro ${ }^{2}$ \\ ${ }^{1}$ Department of Food Technology, \\ ${ }^{2}$ Department of Chemical Enginering, \\ ${ }^{1,2}$ University of Pembangunan Nasional "Veteran” JawaTimur, Surabaya, Indonesia \\ E-mail: $\underline{\text { swin tpupn@yahoo.com }}$
}

\begin{abstract}
There are many variations of Yam (Dioscorea spp.) which spread out in the world including Indonesia. Those variations could be categorized based on their shape, size, colour, and flavour of their tuber. The genus of Dioscorea spp. has more than 600 species, such as Dioscorea hispida, Dioscorea esculenta (lesser yam), Discorea bulbifera, Dioscorea alata (purple yam), Dioscorea opposita (white yam), Dioscorea villosa (yellow yam), Dioscorea altassima, and Dioscorea elephantipes. At the present, the utilization of yam tubers is seen to be limited. The purpose of the research was to evaluate the properties/characteristics of dried synbiotics yoghurt from lesser yam tubers. The treatment on this study was performed by the number of substitution of lesser yam tubers and the fermentation time. The results show that the dried synbiotics yoghurt that most preferred by consumers was $\mathrm{G}_{2} \mathrm{~F}_{3}$ (lesser yam $40 \%$ and fermentation time 22 hours) with an average value 3.65. It is followed by the total LAB (lactic acid bacteria) $8,15 \log \mathrm{cfu} / \mathrm{g}, \mathrm{pH} 4.27$, total lactic acid $1.02 \%$, yield of dried synbiotic yoghurt $32.30 \%$, and total soluble protein $4.53 \%$.
\end{abstract}

Keywords: synbiotic dried yoghurt, lesser yam, Dioscorea esculenta, lactic acid bacteria

\section{INTRODUCTION}

One of the food products being developed recently is a functional food. Functional food is defined as the food that provides beneficial effects for health apart from the fulfillment of basic nutritional needs. One example of a functional food is the one that is containing probiotic bacteria and prebiotic compound.

Probiotics are foods supplements which contain live microbial that have beneficial effects on the health of its host. The function of probiotics includes the following; improving gastrointestinal health, suppresses the growth of pathogenic bacteria, synthesizes vitamins and protein, helps in the absorption of nutrients, aids to overcome lactose intolerant, as well as stimulate immune function (Pompei, et.al, 2008).

Prebiotics is food components that cannot be digested in the upper gastrointestinal tract. They selectively stimulate the growth and activities of beneficial bacteria in the digestive tract, such as Bifidobacterium and lactobacilli, so as to improve the health of the host (Gibson, 2004; Pompei et al., 2008; Gaggia et al., 2010). One prebiotic that is widely used in food formulations is inulin. Lesser yam tuber contains the highestinulin among other Dioscoreaspp. That is $14.77 \%$ (db) (Winarti et al., 2011).

Food products containing probiotics and prebiotics are called synbiotic. The synbiotic product needs to be developed in order to increase the level of consumption of food containing probiotic bacteria and prebiotic compound. Various synbiotic food products such as ice cream, yoghurt, yakult, a fermented beverage and kefir can be developed.

Yoghurt is a fermented milk product made by lactic acid bacteria fermentation. Yoghurt can be made from any milk, including soy milk. In the process of fermentation, the milk sugar (lactose) hydrolyzes to produce lactic acid, which contribute to the flavor and odor of yoghurt. Milk proteins produce a gel-like texture and a unique smell on yoghurt.

This research will improve the utilization of lesser yam to produce synbiotics yoghurt. Yoghurt synbiotic from lesser yam tubers containing inulin as prebiotic compound and combined with probiotic bacteria (bifidobacteria and lactobacilli) will produce new products that are beneficial to health.

In this study, the properties of dried synbiotic yoghurt using fermented milk as a carrier of probiotic bacteria and lesser yam extract as a source of prebiotic were evaluated. Probiotic bacteria were used in this study Bifidobacterium breve BRL-131 and Lactobacillus casei FNCC-90 that has been shown the prebiotic activity 1.071 and 1.21 respectively (Winarti, et .al. 2013).

The purpose of this study was to evaluate the levels of lesser yam tubers and fermentation time on the quality and consumer acceptance of dried synbiotic yoghurt from lesser yam tuber.

\section{METHODOLOGY}

Materials

Lesser yam tuber (Dioscoreaesculenta L.) was obtained from traditional markets in Surabaya East Java. 
Supporting materials, i.e. Na-pyrophosphate, eggs, whipping cream, skim milk, sugar, cocoa powder, essence, cooking oil, ovalet, salt and add coloring.

Probiotic bacteria consisted of Bifidobacterium breve BRL-131 and Lactobacillus casei FNCC-90 obtained from the Food Nutrition Culture Collection, Food and Nutrition Study Centre, Universitas Gadjah Mada. That media used to the growth of bifidobacteria and lactobacilli were MRS broth and MRS agar.

\section{Equipments}

Spectrophotometer Spektronic 21D, autoclave, cabinet dryer, centrifuge, water bath shaker, mixer, viscometer, $\mathrm{pH}$ meter, incubators, and Quebec colony counter. Equipment for the processing of lesser yam tubers includes; flour grinding machine (disk mill), dryers (cabinet dryer), the packaging tool (sealer), oven, blender, mixer, stove, baking molds and plastic tools.

\section{Procedures for making dried synbiotics yoghurt}

Procedures for making synbiotic yoghurt lesser yam tubers are as follows: firstly, mixing all of the ingredients which include lesser yam tubers filtrate, sucrose, and skim milk. Secondly, heating (pasteurization) at a temperature of $70-80^{\circ} \mathrm{C}$ for 15 seconds. Then, mixing and stirring all of the ingredients. Last step was cooling off at a temperature of $\pm 40-45^{\circ} \mathrm{C}$. The mixture was inoculated with starter culture using Bifidobacteria breve BRL-131 and Lactobacillus casei FNCC-90 and incubated at $37^{\circ} \mathrm{C}$ for 18,20 and 22 hours.

\section{Calculation of total lactic acid bacteria}

One $g$ of the sample was homogenized with 1:10 PBS buffer (w/v) 10\%; then glycerol was added, and the samples were frozen $-80^{\circ} \mathrm{C}$, before the calculation of the total cells. Total lactobacilli calculated by pour plate method using MRS agar medium (MRS broth plus $1.2 \%$ technical agar and $0.8 \%$ of $\mathrm{CaCO}_{3}$ ) (Chun et al., 2007). Total bifidobacteria calculated using BSM-Agar (Bifidus Selective Medium-Agar), total E.coli calculated using media TBX (Tryptone Bile XGlucuronide) with a pour plate method.

\section{Total acid (Fardiaz, 1992)}

A level of total acid was calculated as total lactic acid. The analysis is as follows: weighing $3 \mathrm{~g}$ of the sample and add $30 \mathrm{ml}$ of distilled water. The solution was titrated with $0.1 \mathrm{~N} \mathrm{NaOH}$ using indicators PP $1 \%$ until it changes color into pink. Lactic acid was calculated by the formula:

$\frac{\mathrm{mlNaOH} \times \mathrm{N} \mathrm{NaOH} \times 90}{\text { g sample x } 1000} \times 100 \%$

\section{Total soluble protein}

Total soluble protein analysis by the Lowry method. In this method combines the biuret reagent with another reagent (the Folin-Ciocalteau phenol reagent) which reacts with tyrosine and tryptophan residues in proteins. This gives a bluish color which can be read some where between 500-750 $\mathrm{nm}$ depending on the sensitivity required. There is a small peak around 500 $\mathrm{nm}$ that can be used to determine high protein concentrations and a large peak around $750 \mathrm{~nm}$ that can be used to determine low protein concentrations.

\section{A consumer test dried synbiotic yoghurt}

The quality of food can be determined in three ways: chemical, physical and sensory/organoleptics. The acceptance of the food products by consumers was primarily determined by the organoleptic quality. Organoleptic properties is the nature of the materials began using human senses are senses of sight, smell and taste. The organoleptic properties of dried synbiotic yoghurt wich determined was the consumer acceptance to the overall quality included of color, flavor, aroma and softness.

\section{RESULTS AND DISCUSSIONS}

\section{Total lactic acid bacteria}

The results show that the fermentation time and the levels of lesser yam tubers effect on the total lactic acid bacteria in dried symbiotics yoghurt were produced (Figure 1). Increasing in the fermentation time and levels of lesser yam tubers can lead to increase in the total lactic acid bacteria in the yoghurt. The increase of total lactic acid bacteria was caused by nutrition is still available in fermentation 18 and 20 hours, so the bacteria's growth is maximized. Lesser yam tubers contain inulin as prebiotic compounds that may stimulate the growth of bacteria. This result supported by Roberfroid (2005), that dietary inulin can be used to support the health and performance (well-being) and reduce the risk of diseases, and inulincan increase bacteria growth such as Lactobacillus spp. and Bifidobacteriumspp.

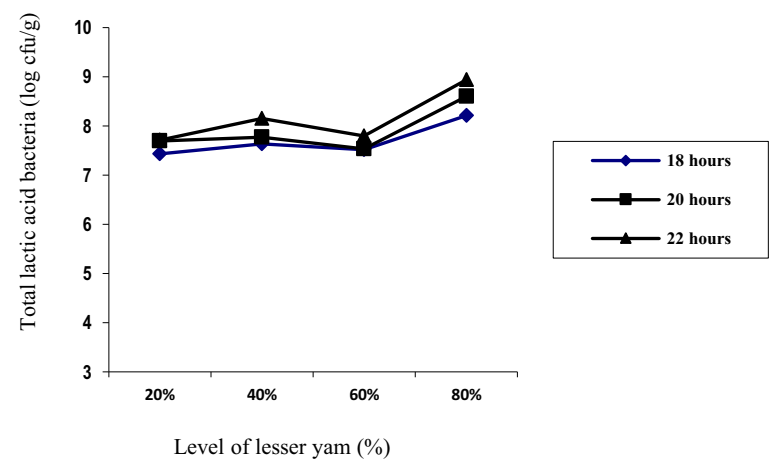

Figure-1. Effect of lesser yam tubers and fermentation time to total lactic acid bacteriaon driedsynbioticyoghurt

Inulin can be increases the growth of Bifidobacterium adolesentis, Bifidobacterium infantis, Bifidobacterium breve, Bifidobacterium longum, Lactobacillusplantarum, Lactobacillus rhamnosus, Lactobacillus reuteri, Lactobacillus delbruechii and 
inhibit the growth of E. coli and Clostridia (Pompei et al. 2008).

\section{PH value of synbiotic yoghurt}

The results show that increasing of fermentation time and levels of lesser yam extract can cause a reduction in the $\mathrm{pH}$ of synbiotic yoghurt (Figure 2). The decrease in the $\mathrm{pH}$ yoghurt was caused by lactic acid which was produced by the bacteria. This result supported by Roberfroid, (2006) who states that the $\mathrm{pH}$ value is affected by the acid produced, due to the increase of lactic acid will lead to the increasing number of $\mathrm{H}$ ions are released. Increased lead-free $\mathrm{H}$ ions decrease the $\mathrm{Ph}$.

Bifidobacterium spp. and Lactobacillus spp. are a group of lactic acid bacteria that produce lactic acid and other organic acids during fermentation. The acid produced by the bacteria group will lower the $\mathrm{pH}$ of the growth medium (Kaur et al., 2011).

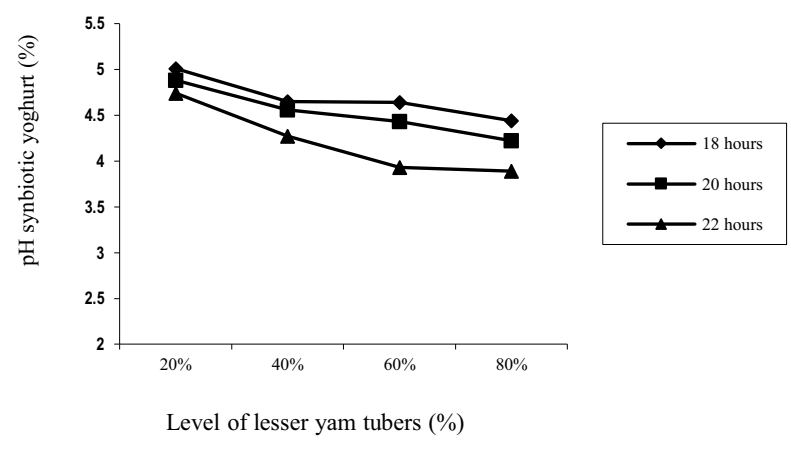

Figure-2.Effect of fermentation time and level of lesser yam extract to $\mathrm{pH}$ synbiotic yoghurt

\section{Total acid of synbiotic yoghurt}

The results show that increasing fermentation time and levels of lesser yam extract increased the total acid of synbiotic yoghurt (Figure 3.). Increasing total acid was caused by increasing the total lactic acid bacteria. This result supported by Matsuzaki in Farnworth (2003), who states that homo fermentative lactic acid bacteria that produce lactic acidis the main product in the fermentation process.

Inulin is fructan, metabolized by lactic acid bacteria through the glycolytic pathway to produce pyruvate, and then pyruvate converted into Acetyl-co-A, lactate and succinate. Acetyl-co-A can be converted to acetate, butyrate, whereas succinate converted to propionate and formate converted to $\mathrm{H}_{2}, \mathrm{CH}_{4}$ and/or $\mathrm{H}_{2} \mathrm{~S}$ gas (Macfarlane and Macfarlane, 2003).

\section{Yield of dried synbiotic yoghurt}

Effects of the fermentation time and level of yam tubers to yield dried synbiotic yoghurt can be seen in Figure 4.

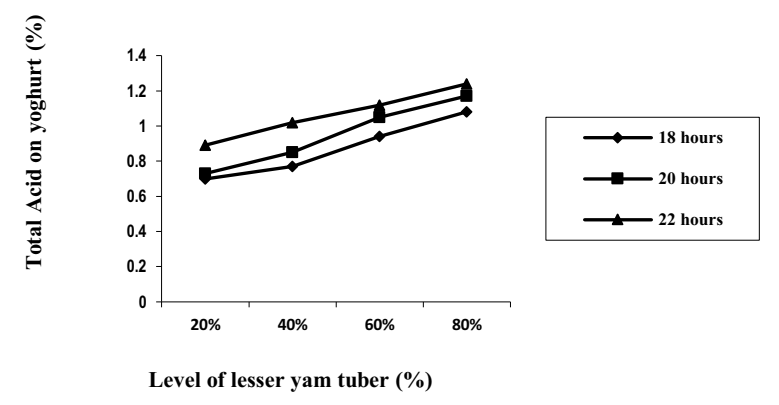

Figure-3.Effect of fermentation time and level of lesser yam extract to total lactic acid in synbioticyoghurt

Increasing the level of lesser yam tubers can increase the yield of dried synbiotic yoghurt whereas increasing fermentation time reduced the yield of dried synbiotic yoghurt. That is occurred because the increasing lesser yam tubers will increase the total soluble solids, so that after drying process, the total soluble solids were added to the total weight of dried synbiotic yoghurt. Increasing fermentation time causes more complex compounds hydrolyzed/broken down by bacteria into simple compounds with smaller molecular weight. The small molecules have the ability to trap water lower than large molecules so that more water can be evaporated in drying process and reducing total dry weight in dried synbiotic yoghurt.

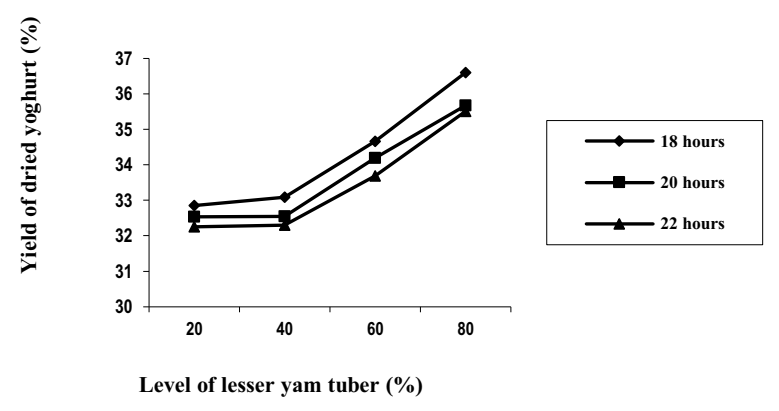

Figure-4.Effect of fermentation time and level of lesser yam extract to yield of dried synbiotic yoghurt

Inulin is fermented by anaerobic bacteria colonies of Bifidobacterium spp. because some of Bifidobacterium spp. produce extracellular inulinase enzymes that hydrolyzed the $\beta$ - $(2,1)$-fructosil-fructose bond to produce fructose that can be used as an energy source for the growth of Bifidobacteriumspp. (Robertfroid, 2005).

\section{Total soluble protein of dried synbiotic yoghurt}

The results show that the increasing fermentation time increased the levels of total soluble protein in dried synbiotic yoghurt while increasing lesser yam tubers reduced the levels of total soluble protein. The average value of soluble protein content on dried synbiotic yoghurt can be seen in Figure 5. 


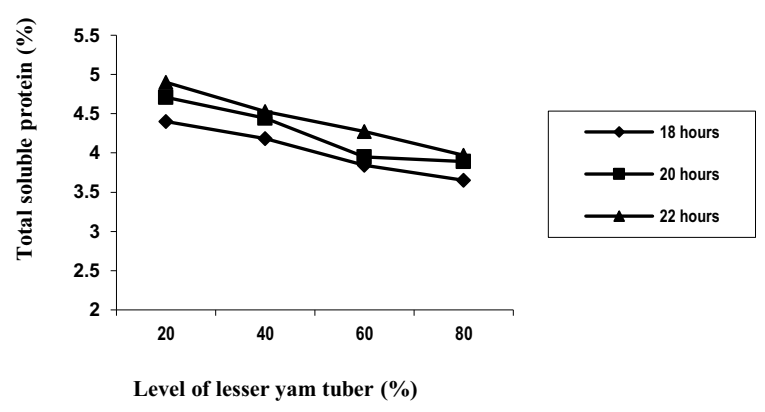

Figure-5.Effect of fermentation time and level of lesser yam extract to total soluble protein of dried synbiotic yoghurt.

Increasing the fermentation time can increase the levels of soluble protein; this is caused by increasing growth of lactic acid bacteria (LAB), which have the ability to hydrolyze proteins to produce small peptide compounds. These compounds are easier to dissolve in water. Widodo (2003), who states that in order to grow properly, lactic acid bacteria, must be able to ferment lactose, hydrolyze proteins and produce amino acids from proteolysis process. Protein degradation is done by lactic acid bacteria with proteolytic enzyme complex including the proteinase and peptidase enzyme. The first stage of protein degradation by the proteinase enzyme occurs on the surface of bacterial cells thus producing oligopeptides and amino acids which would then be further degraded by peptidase enzymes to produce amino acids.

Increasing the lesser yam tubers reduced the levels of soluble protein in the dried synbiotic yoghurt. It was becaused the largest component in the lesser yam tubers are carbohydrates. In accordance with the results of the first phase, it is known that starch content of lesser yam tuber is $82.82 \%$.

\section{Consumers preference of dried synbiotic yoghurt}

The quality of food can be determined in three ways: chemical, physical and sensory. The acceptance of food products by consumers is determined by the quality of sensory factor. Sensory properties are the natural of the starting material using human senses such as the sense of sight, smell and taste. The consumer's acceptance of the sensory properties of dried symbiotic yoghurt is due to the overall quality of color, flavor, smell and softness.

The results of research show that fermentation time and levels of lesser yam tubers have an effect on consumer preference to dried synbiotic yoghurt. Effect of fermentation time and levels of lesser yam extract to synbiotic yoghurt can be seen in Figure 6. The dried synbiotic yoghurt most preferred by consumers was for the treatment of lesser yam tubers $40 \%$ and fermentation time 22 hours $\left(\mathrm{G}_{2} \mathrm{~F}_{3}\right)$.

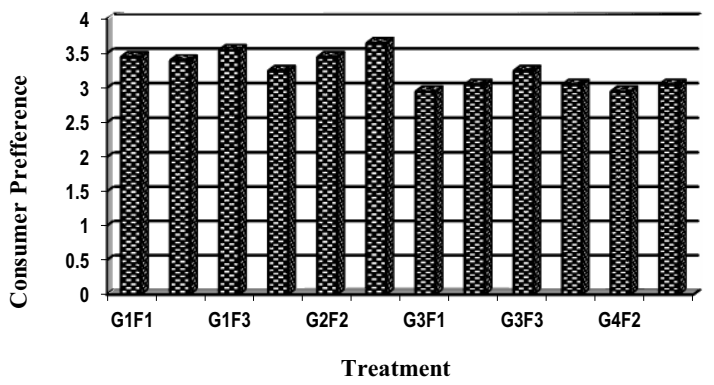

Figure-6.Effect of fermentation time and levels of lesser yam extract to consumer preference of dried symbiotic yoghurt

\section{CONCLUSION}

The research can be concluded that the levels of lesser yam tubers and fermentation time have significant effect on the quality of dried synbiotics yoghurt. The most consumers preferred of dried synbiotics yoghurt was $\mathrm{G}_{2} \mathrm{~F}_{3}$ (the addition of lesser yam $40 \%$ and fermentation time 22 hours), with an average value of 3.65; and has the following characteristics: total LAB (lactic acid bacteria) of $8.15 \log \mathrm{cfu} / \mathrm{g}, \mathrm{pH} 4.27$, a total lactic acid of $1.02 \%$, yield of dried synbiotic yoghurt $32.30 \%$,and $4.53 \%$ of total soluble protein.

\section{REFFERENCES}

Arrizon, J., Morel, S., Gschaedler, A. and Monsan, P.(2010). Comparison of the water-soluble carbohydrate composition and fructan structures of Agave teguilana plants of different ages. Food Chemistry122:123-130.

Berghofer, E., Cramer, A., Schmidt, V., and Veighl, M. (1993). Pilot-scale production of inulin from chicory roots and its use in food stuffs. In. Inulin and Inulincontaining crops. Elsevier Science, Amsterdam.

Gibson, G.R., Beatty, E.R., Wang X., and Cummings J.H. (1995). Selective stimulation of Bifidobacteria in human colon by oligofructosa and inulin. Gastroenterology; 108:975-982.

Gibson, G.R., Cartney, A.L.M. and Rastall, R.A. 2005. Prebiotics and resistance to gastrointestinal infection. The British Journal of Nutrition, (93), Suppl 1, pp 531534.

Huebner, J., Wehling, R.L. and Hutkins, R.W. (2007). Functional activity of commercial prebiotics. International Dairy Journal. 17:770-775.

Kaur, A., Rose, D.J., Rumpagaporn, P., Peterson, J.A. and Hamaker, B.R. 2011. In vitro batch fecal fermentation comparation of gas and short-chain fatty acid production using "slowly fermentable" dietary fibers. Journal of Food Science, (04):111-116. 
Macfarlane, S. and Macfarlane, G.T. 2003. Regulation of short-chain fatty acid production. Proceedings of the Nutrition Society, 62:67-72.

Oliviera, R.P.D.S., Perego, P., Oliviera, M.N.D. and Converti, A. (2011). Effect of inulin as a prebiotic to improve growth and count of a probiotic cocktail in fermented skim milk. Food Science and Technology 44: 520-523.

Pompei, A.,Cordisco, L., Raimondi, S., Amaretti, A. and Pagnoni, U.M. (2008). In vitro comparation of the prebiotic effect of two inulin-type fruktans. Anaerob14:280-286.

Roberfroid, M.B. (2005). Introducing inulin-type fructans. British Journal of Nutrition 93: Suppl.1,S13S25.

Sardesai, VM. 2003. Introduction to Clinical Nutrition. $2^{\text {nd }}$ Ed. USA: Marcel Dekker, Incon: Herb.

Toneli, J.T.C.L., Park, K.J., Ramalho, J.R.P., Murr, F.E.X. and Fabbro, I.M.D. (2008). Rheological characterization of chicory root (Cichoriumintybus L.) inulin solution. Brazilian Journal of Chemical Engineering25:03: 461-471.

Wang, X., G.W. Yuan, Z. LiMing, X. PeiGen, Y. LiPing, L.Yi, L.KeFeng and X.W.Guang. 2008.Study on the morphology, crystalline structure and thermal properties of yam starch acetates with different degrees of substitution. Sci China Ser B-Chem, Vol.51 no.9:859865 .

Widodo, 2003. Biotechnology Milk Industry, Kanisius Press, Yogyakarta.

Winarti, S.; Harmayani, E and Nurismanto, R. 2011. Characteristics and Profile of Inulin from Various Yam Tubers (Dioscoreaspp.). AGRITECH, Vol.31, No.4: 378-383

Winarti, S., E.Harmayani and R.Nurismanto. 2011. Ekstraction of inulin from various yam tubers (Dioscorea spp.), article was presented in AFC (Asian Food Conference), Bangkok 15-19 June 2011.

Winarti, S., Harmayani, E., Marsono, Y., and Pranoto, Y. 2013. Effect Foaming on Drying Inulin from Lesser Yam Tubers (Dioscoreaesculenta) to Phisichochemical Characteristics Prebiotics Activity. AGRITECH, 33(4):311-319.

Winarti, S., Harmayani, E., Marsono, Y., and Pranoto, Y. 2013. Effect of inulin isolated from lesser yam (Dioscoreaesculenta) on the growth of probiotics bacteria and SCFA formation during fermentation. International Research Journal of Microbiology (IRJM), Vol 4(2): 53-63.

Winarti, S., Harmayani, E., Marsono, Y., Pranoto, Y., Nishi, K., and Sugahara, T. 2014.Immunostimulatory and Prebiotic Activities of Inulin Extracted from Lesser
Yam Tuber (Dioscoreaesculenta). Bali International Seminar on Science and Technology (BISSTECH 2). UPNV Jatim and STIKOM Bali. Denpasar,2-4 September 2014.

Winarti, S., Harmayani, E., Marsono, Y., and Pranoto, Y. 2014.Quantification of Colonic Microbiota Sprague Dawley Rats with Diet Containing Lesser Yam Inulin by Florescent in Situ Hybridization (FISH) Method. International Converence Food for a Quality Life. SEAFAST CENTER and PATPI. Jakarta, 15-16 Oktober 2014. 